\title{
Caring for the mentally ill
}

I did a stint as a locum psychiatry registrar in a large London hospital in 1995, where I first came across some of the consequences of the deinstitutionalisation of the mentally ill. Late on a Sunday afternoon a distraught family contacted me about their mentally ill brother, who had been managed in the community for some time. Although generally well controlled on medication, he was decompensating and at that time on a weekend, their only recourse was to a busy emergency department of a large hospital. And here their point of contact was a locum, from another country, with no specialised training in psychiatry. I probably wasn't an awful lot of use to them, and, unable to contact their normal GP or community mental health practitioner, I landed up admitting the patient. I am sure that this was an enormous relief to the family, who had been struggling for days, but it suggested to me that dealing with the mentally ill in the community was difficult. And this was in the UK, with all the massive public resources they have available.

Driving along the M3 highway in Cape Town, I regularly used to see a young man under the various bridges - sometimes naked, sometimes in a wetsuit, and once with an old telephone handset held to his ear (perhaps rationalising where the voices were coming from). I haven't seen him for some time, but there are other similar people on the various routes that I travel. I am sure that not all of them represent failures in community care of the mentally ill, but some of them must do.

The Life Esidimeni tragedy threw some of these failures into full and appalling view. The Health Ombud's report was into the '... circumstances surrounding the deaths of mentally ill patients transferred ... to community-based facilities' - my emphasis. South Africa (SA) escalated the pace of deinstitutionalisation of the mentally ill following the promulgation of the Mental Health Care Act 17 of 2002, but, as pointed out in the editorial in this issue by Lesley
Robertson and colleagues, ${ }^{[1]}$ this was not accompanied by the necessary development of community-based services. A key recommendation (Recommendation 16) of that report speaks to the future of mental healthcare in SA, again pointing to the need for full communitybased mental health resources. In Gauteng at least, it would appear that the failure is intimately linked to poor budget planning - how money has not 'followed the patient'. It is also apparent that, again in Gauteng at least, the amount of money allocated for mental health is woefully short of the minimum recommended by the World Health Organization. Furthermore, while the budget for pyschiatric hospitals had increased over the past few years, that for community-based mental health services had fallen.

The mentally ill are some of the most vulnerable in our society and deserve the best of care. In this same issue, Ames Dhai ${ }^{[2]}$ quotes Steve Biko: 'In time, we shall be in a position to bestow on South Africa the greatest possible gift - a more human face.' We as health professionals need to make that happen.

\section{Bridget Farham \\ Editor \\ ugqirha@iafrica.com}

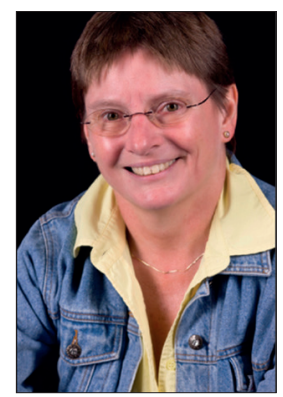

Robertson LJ, Janse van Rensburg B, Talatala M, et al. Unpacking Recommendation 16 of the Health Ombud's report on the Life Esidimeni tragedy. S Afr Med J 2018;108(5):362-363. https://doi. org/10.7196/SAMJ.2018.v108i5.13223

2. Dhai A. The Life Esidimeni tragedy: Moral pathology and an ethical crisis. S Afr Med J 2018;108(5):382 385. https://doi.org/10.7196/SAMJ.2018.v108i5.13232

S Afr Med J 2018;108(5):358. DOI:10.7196/SAMJ.2018.v108i5.13330 